\title{
Reply to Comment of Finger et al. (2013) on: 'Evidence for an Early-Middle Miocene age of the Navidad Formation (central Chile): Paleontological, paleoclimatic and tectonic implications' of Gutiérrez et al. (2013, Andean Geology 40 (1): 66-78)
}

\author{
Jacobus P. Le Roux ${ }^{1 *}$, Néstor M. Gutiérrez ${ }^{1}$, Luis F. Hinojosa ${ }^{2}$, Viviana Pedroza ${ }^{3}$, Juan Becerra ${ }^{1}$
}

\author{
'Departamento de Geología, Facultad de Ciencias Físicas y Matemáticas, Universidad de Chile/Centro de Excelencia en Geotermia \\ de los Andes (CEGA), Plaza Ercilla 803, Santiago \\ jroux@cec.uchile.cl; gutierrezn@ug.uchile.cl; jbecerra@ing.uchile.cl \\ ${ }^{2}$ Laboratorio de Paleoecología, Facultad de Ciencias-Instituto de Ecología y Biodiversidad (IEB), Universidad de Chile, Las Palmeras 3425 , \\ Santiago, Chile. \\ lfhinojosa@uchile.cl \\ 3 Escuela de Ingeniería Geológica, Facultad Seccional Sogamoso, Universidad Pedagógica y Tecnológica de Colombia, Avenida \\ Central del Norte 39-115, Boyacá, Colombia. \\ viviana.pedroza@uptc.edu.co
}

*Corresponding author:jroux@cec.uchile.cl

We thank Finger et al. (2013) for their discussion of our paper and appreciate their honesty in retracting the proposed Late Miocene-Pliocene age for the Navidad Formation, due to misidentification of the foraminifer index species in question. In fact, although we suspected all along that these species may have been misidentified, such an allegation seemed improper to us in view of the recognized expertise of Dr. Finger as a micro-paleontologist, whereas none of us can claim such knowledge. That left us with no other option but to suggest the earlier appearance of these species in the southeastern Pacific Ocean than elsewhere. Finger et al. (2013) summarize most of the pertinent information on the Navidad Formation mentioned in our paper, reiterating their interpretation of the depositional environment as a middle bathyal (at least 1,500 m depth; Encinas, 2006), continental slope in contrast to our proposal of a continental shelf. While we agree on most of the facts, it seems to us that Finger et al. (2013) have a tendency to turn a blind eye to the latter.

\section{Age of the Navidad Formation}

Finger et al. (2013) state that our assessment of published data overwhelmingly favoring an Early to Middle Miocene age 'is misleading', citing various previous studies indicating the opposite. However, we referred to the published data, not the interpretation of this published data, and pointed out that almost all the species previously considered as occurring only in Upper Miocene to Pliocene strata have in fact been found elsewhere in Lower to Middle Miocene successions.

\section{Molluscan biostratigraphy}

Finger et al. (2013) contend that we 'do not recognize that all benthic animals are controlled by bottom facies that can be geographically diacronous'. Even though we are not invertebrate paleontologists, we know enough about paleontology not to ignore this concept. Our Early to Middle Miocene age 
interpretation for the molluscs in the Navidad Formation was based mainly on $\mathrm{Sr}$ isotope data from various sources, including those of Encinas (2006), Nielsen and Glodny (2006), and our own (Gutiérrez, 2011), which all indicate this age range. The fact is that the latter agrees with that of the successions in Peru where the same species also occur.

We do not agree that the molluscs have been transported from shallow to deeper water by turbidity currents, as indicated by their well-preserved, delicate ornamentation, articulated valves, the fact that the sediment matrix within their shells is the same as that of the surrounding host, and their clear lithofacies associations. In situ deposition is supported by the abundance of complete leaves and the presence of articulated crabs (Fig. 1). We are surprised that Finger et al. (2007) ignored such clear signals of in situ preservation and continue to do so in their discussion. In the sandstone package at Punta Perro, for example, many shallow water molluscs such as Turritella occur both dispersed throughout the succession and concentrated in lenses. At this locality and in the same sandstone package, the presence of wave ripples clearly indicates shallow water. Furthermore, to suggest that turbidity currents are 'non-abrasive flows' negates all we know about this phenomenon-velocities exceeding $120 \mathrm{~km}$ per hour and extreme turbulence capable of breaking telegraph cables (e.g., Fine et al., 2005) can hardly be described as 'non-abrasive'. It would be hard to imagine delicate insect body parts (Fig. 2) surviving such a process. The occurrence of rocky shoreline mollusc species (Nielsen et al., 2004) in 'deep water sandstones' would also require some turbidity currents to have originated at the shoreline and to have transported them across the continental shelf, which in view of the typical low gradient of the latter $\left(0.1^{\circ}\right)$ is unlikely.

A 'somewhat chalky surface texture' in some molluscs is a very weak argument against their in situ occurrence, as it completely ignores modern weathering processes. The proposal of Finger et al. (2007) that these molluscs were reworked from older rocks is no longer valid, and if they were eroded from contemporaneous sediments on the continental shelf and transported by turbidity currents into deeper water (within at most a few hours), this would definitely not change a fresh surface into a chalky texture. It would therefore make no difference whether they occurred in situ on the shelf (which is what we maintain) or
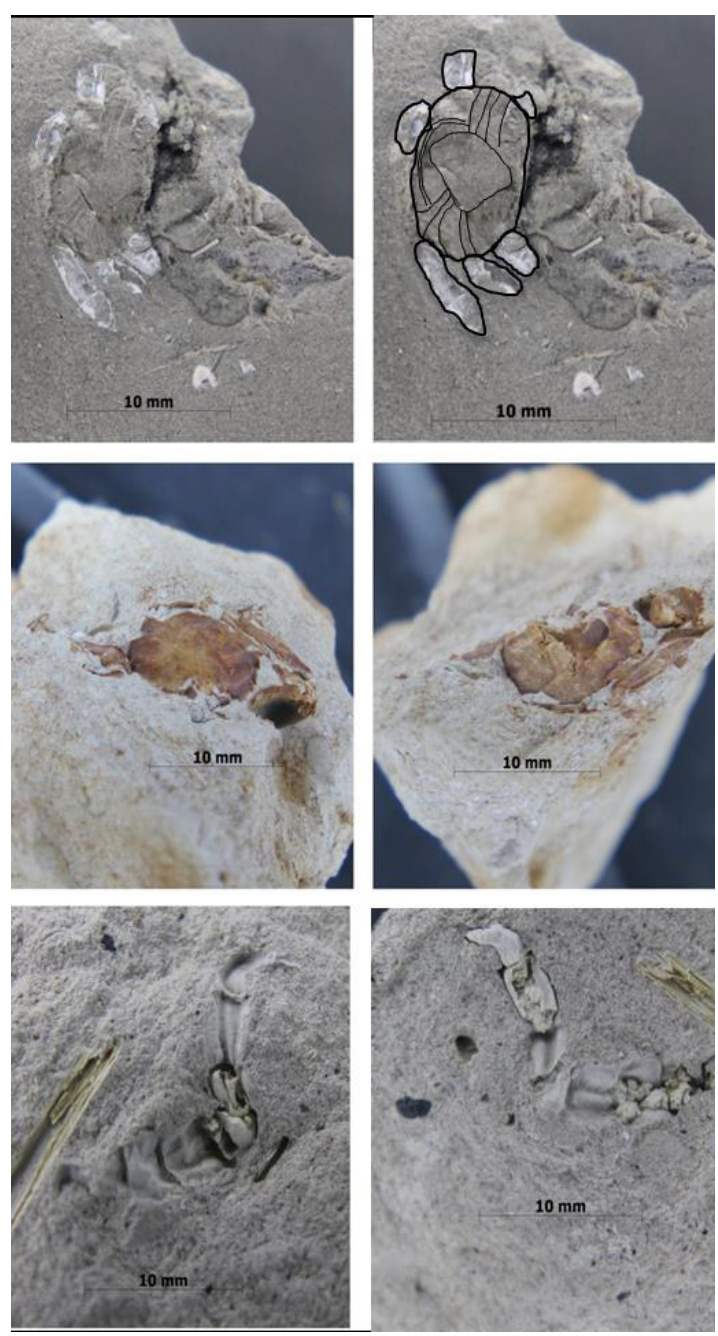

FIG. 1. Unidentified, articulated crabs in fine-grained sandstones of the Navidad Formation.

were displaced into deeper water. Neither do we see why their preservation in fossil-rich lenses must indicate long distances of transport, because even small, local channels, common for example at Punta Perro, can reconcentrate organisms.

\section{Strontium isotope stratigraphy}

We cited Nielsen and Glodny (2006) on p. 69 of our paper, in which they reported $21 \mathrm{Sr}$ ages ranging between 24.3-16.1 Ma. Their 2009 publication did not contribute any new, contradicting data. As concerns the problem with the stratigraphic order, we acknowledge that small discrepancies are present 


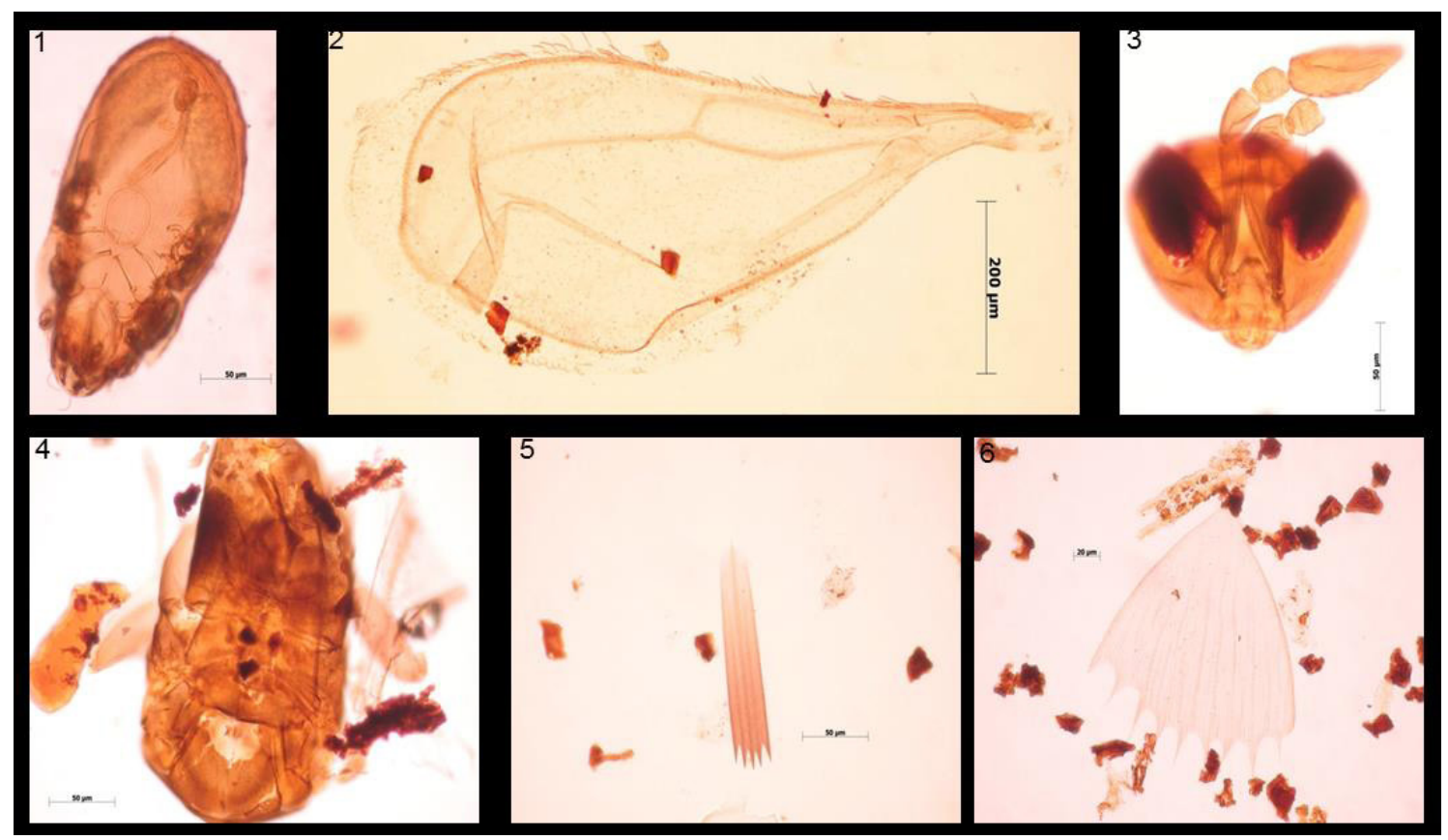

FIG. 2. Delicate insect body parts, including head, thorax, and wings, preserved in the Navidad Formation.

between individual samples, as also shown in our Table 3. However, it should be kept in mind that after-death recrystallization from aragonite to calcite, especially prominent in gastropod shells, might alter the obtained $\mathrm{Sr}$ ages somewhat. Nevertheless, all the $\mathrm{Sr}$ ages in our lower member are within the range 22.1-16 Ma and there is a general decrease in age up the column, which is consistent with a decrease in the ${ }^{40} \mathrm{Ar} /{ }^{39} \mathrm{Ar}$ ages from 26.1-18.9 Ma. The upper member also yielded a stratigraphically consistent ${ }^{40} \mathrm{Ar} /{ }^{39} \mathrm{Ar}$ age of $12 \mathrm{Ma}$. Although the $\mathrm{Sr}$ dates may not be precise due to neomorphism, we do not consider this to be a major problem in the light of the overwhelmingly Early Miocene ages for the lower member and Middle Miocene age for the upper member, especially now that this has been confirmed by a reinterpretation of the foraminifer ranges.

\section{Radiometric dating}

Our argument concerning Middle Miocene scoria ages from the Navidad Formation was that this material reflects contemporaneous volcanism, where ash covering the landscape around volcanoes after an eruption would be immediately eroded and transported to be deposited as discrete beds in the Navidad Formation, thus reflecting the true age of the latter. Finger et al. (2013) seem to have misunderstood this point, as they originally argued that the volcanic material was eroded from older, Middle Miocene strata, not we.

\section{Ostracods and pollen}

With the exception of one ostracod, Bradleya normani, all the identified diatoms and ostracods have also been found in Lower and/or Middle Miocene strata. Bradleya normani is a very rare species, so it is not surprising that it had not yet been found in older strata. In fact, the Navidad Formation is the first such occurrence, as even Finger et al. (2013) now concede to its Early to Middle Miocene age.

\section{Planktic foraminifers}

Finger et al. (2007) dismiss the hypothesis that five index species of foraminifers occurred in the southeastern part of the Pacific before elsewhere in the global ocean 'without hesitation'. Before 1938, they would have said the same if we had discovered a coelacanth at Punta Perro. 
We all know very well that micropaleontological dating largely stands upon its own shoulders. A look at classic biostratigraphic charts (e.g., that reproduced in Encinas, 2006) shows that 3 index species, including Neogloboquadrina acostaensis, appeared simultaneously and globally at 10.9 Ma. The Sr date of $12.1 \pm 0.7$ obtained by Encinas (2006) on $N$. acostaensis was thus rejected because it is too old. However, now that Finger et al. (2013) have reidentified $N$. acostaensis as another species they would reject this age again because it is too young, seeing that they now consider all their samples to be from the Burdigalian (20.4-16.0 Ma). This, unfortunately, is how micropaleontological dating frequently operates: stratigraphic units are considered to be of a certain age because certain index species occur in them, and if absolute dating suggests otherwise, it may be rejected because it does not coincide with the 'established ranges'. We are therefore not particularly impressed by the 'voluminous amount of global data'.

We should point out that Dr. Finger, as a renowned foraminifer expert, based his identification of Neogloboquadrina acostaensis and Globorotalia puncticulata on illustrations in the primary reference guides to the Oligocene-Recent microfauna (Kennett and Srinivasan, 1983; Bolli and Saunders, 1985; Jenkins, 1985), 'and their identified images were not questioned when shown to several experts.' Neither could two New Zealand experts, Drs. Crundwell and Scott, 'assign either form definitively to any other species'. Furthermore, in the Miocene, faciesequivalent Caldera Basin, the same two index species were identified by Dr. Scott E. Ishmann, who did not suspect their assignation (Achurra, 2004). We must therefore conclude that at least these two species are so similar to the 'real' index species that several world experts could not see the difference. This brings us to the age-old question of where to draw the line between species, and it seems that even Dr. Finger and co-workers were doubtful of this aspect until very recently. According to their own admission, they knew since 2010 that these foraminifers had been misidentified, in fact belonging to the EarlyMiddle Miocene, and yet apparently continued to question such an age. For example, in Rodríguez et al. (2012), a paper of which Dr. Encinas was a co-author, it is stated: 'If marine deposition inside the Navidad Basin started during the early Miocene, the provenance results would record erosion and deposition contemporary with volcanic activity. On the other hand, if marine deposition started during the late Miocene, the provenance results show a retrograde erosive response to landscape for a regional uplift event proposed for that period for the study area'.

The other three index species, Globoturborotalia apertura, Globorotalia spheriomizea, and Neogloboquadrina pachyderma, are not mentioned in the present discussion. Finger et al. (2013) only note that 'some of our identifications, including those of Neogloboquadrina acostaensis and Globorotalia puncticulata, were incorrect'. 'Some' means 'not all', which implies that not all five species had been misidentified. If so, how could such species then be present in rocks older than their 'established' range if this is so impossible?

\section{Depositional environment}

Finger et al. (2013) based their interpretation of a deep water, bathyal environment mainly on benthic foraminifers, trace fossils, and sedimentological evidence.

Lipps (1993) maintained that deep water benthic foraminifers have shown great evolutionary stability only after $15 \mathrm{Ma}$ and especially after the Late Miocene, in which most of the extant benthic species appeared. There is thus no guarantee that Early Miocene species inhabited the same water depths as their successors. Furthermore, given the turnabout concerning the age of the Navidad Formation based on five(?) misidentified planktic index species, how sure can we be that the benthic foraminifer species do not present a similar situation? Even if correctly identified (which we have to assume), Finger et al. (2013) themselves admit that 'they are not controlled by water depth but by depth-related environmental parameters that are geographically or temporally consistent...it is now recognized that there are no isobathyal species...' In addition, the authors concede that 'an upper depth limit is not definitive-it simply indicates the generalized depth zone above which the species is rarely encountered or abundant'. We are told that there is always a mixture of shallow and deep water species in the Navidad samples, and that 'nearly half of the 63 provincially extant species that account for $22 \%$ of our Miocene fauna have been provincially recorded only from bathyal depths'. If we understand this sentence correctly, only $22 \%$ of 
the Navidad fauna still occur today and of those, less than half are deep water species, which means that only about $10 \%$ of the total number of Navidad species are of deep water origin and that shallow water species largely dominate this succession.

The occurrence of psychrospheric ostracod species, which 'inhabit colder water masses' cannot be used to infer water depths of more than $500 \mathrm{~m}$, as this ignores the effect of upwelling. This is even admitted by Encinas (2006, p. 136, lines 1-2). Similarly, the presence of a hydrocarbon paleoseep in strata of the Navidad Formation is certainly no evidence for a bathyal water depth either, as such seeps can occur in any sedimentary succession where hydrocarbons accumulate. The isotopic characteristics described by Contardo and Mena (2012) indicate a paleoseep, not deep water.

As concerns the sedimentological evidence, we must point out that there are many similarities between, e.g., the deposits of prograding deltas and submarine slope fans, including coarsening-upward successions, the presence of shifting distributary channels, slump structures, slides, synsedimentary faults, water escape structures, and convolute lamination. Even partial Bouma cycles are not unique to slope fans, because turbidity currents can also be generated on delta slopes. However, a sedimentary structure that cannot form on slope fans is symmetrical wave ripple marks, present for example in the Punta Perro sandstone package. Wave ripples can only form where the orbital water particle velocity below waves exceeds the entrainment velocity of the grains, which is generally considered to be at a depth of about half the wavelength (e.g., Duff, 1978). For such waves to affect the continental shelf to a depth of $200 \mathrm{~m}$, therefore, wavelengths of at least $400 \mathrm{~m}$ are required, which implies wind velocities of about $90 \mathrm{~km}$ per hour sustained for at least 33 hours (Le Roux, 2009). It would simply be impossible for waves to affect a slope fan at a depth of 200-1,500 $\mathrm{m}$. At Punta Perro, wave ripples are present spatially and stratigraphically very close to a sedimentary breccia with large rip-up clasts. Although Finger et al. (2013) maintain that such clasts and breccias are 'characteristic of gravity flows typical of deep marine environments', Le Roux et al. (2004), for example, described similar rip-up clasts and breccias in time- and facies-equivalent beds of the Coquimbo Formation north of La Serena, where they occur in a submarine channel crossing the continental shelf.
The absence of hummocky cross-bedding in the Navidad Formation is also not an indication of deep water, as these structures are nowhere common and their associated swales may even be confused with trough cross-beds by the untrained eye. Le Roux and Jones (1994) studied the shelf-deposited Nowra Formation in southeastern Australia, measuring many profiles over an area of more than a thousand square kilometers, and only recorded one instance of hummocky cross-bedding. Encinas (2006) does not mention these structures in the overlying Licancheu and La Cueva Formations, and yet interprets their environment as shallow marine.

The Navidad Formation has several cycles of sandstone packages alternating with siltstone-shale packages (Fig. 3). The sandstone packages are characterized by trace fossils such as Ophiomorpha, Thalassinoides and Skolithos, generally considered to reflect shallow water conditions, and also contain in situ shallow water molluscs such as Turritella, Astele, Ameranella, Lassia, Austrotoma, Lamprodomina, Olivancillaria, and Testallium (Nielsen et al., 2004). Some of these packages contain wave ripples indicating water depths less than $200 \mathrm{~m}$. There is very little, if any, direct evidence that these sandstones were deposited by turbidity currents. Figure 3 also shows that the sandstone packages are practically horizontal, thus lacking the slope required for gravity flows. Flame structures reported at the base of some sandstones are normally associated with load casts, which might easily be confused with flute marks. It would also be rather unusual to have periods of almost continuous turbidity currents depositing heterogeneous sandstone packages of 30-40 m, interspersed with long periods during which turbidity currents apparently ceased to flow while the siltstone-shale packages were deposited. Most turbidite successions worldwide are very homogeneous.

The siltstone-shale packages contain 'deep water' benthic foraminifera, trace fossils such as Zoophycos and Chondrites, and 'deep water' molluscs such as Otukaia, Struthiochenopus, Falsilunatia, Dalium, Adelomelon, and Exilia (Nielsen et al., 2004). However, there is very little information on the actual water depths inhabited by these molluscs in the literature, and 'deep water' is relative. Falsilunatia scothianus, for example, is described as a deep water gastropod, but has only been found at depths between 73 and $298 \mathrm{~m}$ (Welch, 2010). 
Interestingly, the siltstone-shale packages on the seismic profile offshore from Navidad (Fig. 3) show what appear to be seaward-dipping, westwardprograding beds, which might be interpreted as delta slope deposits, whereas the more horizontal sandstone packages could represent delta platform sedimentation.

Nevertheless, we do not have a serious problem with an outer shelf/uppermost continental slope environment for the siltstone-shale packages, which would explain the trace fossils and also the ostracods if upwelling is factored in. But, we cannot imagine repeated, abrupt depth changes from less than $200 \mathrm{~m}$ to a 'minimum of 1,500 m' (Encinas, 2006, p. 136).

The conglomerate at Punta Perro stated by Finger et al. (2013) to overlie a thick siltstone interval with Zoophycos ichnofacies, in fact rests unconformably on Paleozoic basement granitoids. This was also interpreted by Encinas (2006, p. 87 and p. 135) as a basal conglomerate that formed in shallow water. Finger et al. (2013) now maintain that it represents a debris flow deposit that originated from shelf-margin failure, because 'it is unlikely that the boulders were derived from the continent and transported to the outer shelf because the shelf gradient is generally $<1^{\circ}$, which minimizes the ability of large clasts to move long distances'. Once again, it seems that they are ignoring facts to follow fancy. For a Paleozoic plutonic rock to be exposed on surface, a long period of subaerial erosion is required, which means uplift to above sea level. The boulder bed thus represents the first Early Miocene marine transgression at the commencement of Navidad deposition. These boulders must have been rounded and polished by wave action, because there is no known process to round such large boulders at a depth of $1,500 \mathrm{~m}$. If they had been transported, for example, by a tsunami backflow from a contemporaneous beach, they should be associated with structures typically occurring with this phenomenon, such as sandstone injections and large rip-up clasts of the substrate (Le Roux et al., 2004, 2008; Le Roux and Vargas, 2005). The statement by Finger et al. (2013) that "the boulders are associated with a synsedimentary breccia composed of large stratified blocks' is misleading, because this breccia occurs at the other side of the Punta Perro Peninsula where the boulder bed is not even exposed. In the absence of any evidence for a tsunami backflow at this locality we consider this

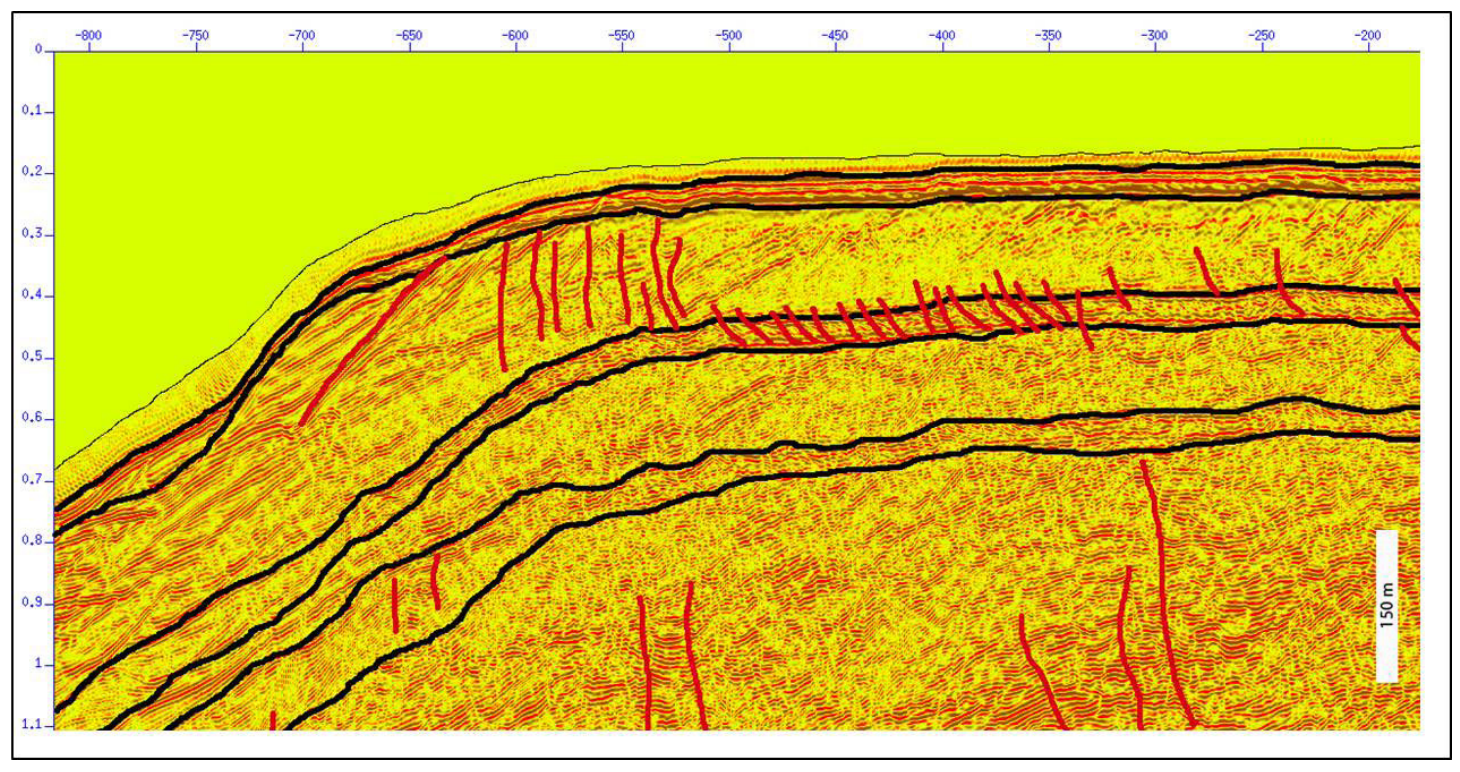

FIG. 3. Seismic profile of the Navidad Formation (modified from Contardo et al., 2008), showing that faults with significant displacement are absent immediately offshore of the outcrops studied on land, which indicates that large-scale crustal thinning did not take place during deposition of the Navidad Formation. The profile also shows 3 prominent sandstone packages alternating with siltstone-shale packages. The sandstone packages might represent delta platform deposits, whereas the siltstone-shale packages show what appear to be westward-sloping, prograding beds possibly reflecting delta slope sedimentation. 
to represent an in situ beach conglomerate, as also attested to by the presence of barnacles (Balanus) in this unit in several different sections measured by Encinas (2006; profiles MEMB, CANEL, PTOR, PALT, and TOP). This interpretation furthermore concurs with the presence of gastropods such as Fissurella, Nerita, and Zonaria in the Navidad sandstones, which according to Nielsen et al. (2004) indicates the presence of 'nearby rocky shores'.

Even if we had to assume for a moment that the Paleozoic basement is overlain by a thick siltstone unit with middle bathyal Zoophycos ichnofacies, in turn capped by the boulder bed, it would mean that the sea level rose abruptly by at least $1,500 \mathrm{~m}$, not leaving any traces of intermediate shelf deposits, and dropped again by the same amount to leave the beach facies of the boulder bed. Such drastic sea-level oscillations would be hard to image under any tectonic regime and certainly cannot be explained by subduction erosion. The latter was attributed by Encinas (2006) and Encinas et al. (2008) to a common event that also affected other sectors in northern and south-central Chile, Peru, New Zealand, Japan and Costa Rica during the Late Miocene-early Pliocene. Subduction erosion according to this theory would have been the direct effect of a decrease in the sedimentation rate in the oceanic trench caused by an increasingly dry climate. Although Meón et al. (1994) recognized a high percentage of Chenopodiaceae in a sample from Punta Perro, which they interpreted as being indicative of dry conditions, Barreda et al. (2011) found very low concentrations of this pollen type and considered its presence to be linked to littoral communities rather than an arid paleoclimate.

In any case, given the now accepted Early to Middle Miocene age, this period was characterized by higher rainfall (Hinojosa, 2005; Hinojosa and Villagrán, 2005; Hinojosa et al., 2006; Gutiérrez, 2011; Gutiérrez et al., 2013), so that an increased sedimentation rate in the trench would have provided the necessary lubrication to prevent subduction erosion. The other possible causes for such a dramatic subsidence are mentioned and discarded by Encinas et al. (2008) themselves: depression of the lower oceanic plate is ruled out by the very small size or absence of accretionary prisms along most of the Chilean margin; and crustal thinning and massive-scale sliding causing extension faulting is not supported by the presence of large faults in seismic profiles (Contardo et al., 2008; Fig. 3).
In the scenario proposed by us, marine transgressions and transgressions of the order of 200-300 $\mathrm{m}$, followed by sea-level stillstands or minor marine regressions were caused by eustatic sea level changes combined with tectonic oscillations, and could easily produce the alternating shallow water sandstone packages and deeper water siltstone-shale packages. However, oscillations of the order of 1,500 m seem highly improbable.

\section{Stratigraphy of the Navidad Formation}

Gutiérrez (2011) primarily studied the floral changes in the Navidad Formation and thus concentrated his efforts on the coastal sector, where plant fossils abound. However, he also carefully mapped the Navidad Formation taking account of faults, so that there is no reason to believe that his stratigraphic correlation is faulty. In fact, on his geological map (Fig. 1 of Gutiérrez et al., 2013), two large NE-trending faults are shown between the coastal sector and the town of Navidad, whereas Encinas (2006) apparently did not recognize these structures. The possibility of facies repetition due to faulting in the Navidad Formation therefore exists, but is not necessarily restricted to the work of Gutiérrez (2011).

We would also like to point out an alternative interpretation to the stratigraphic scheme of Encinas (2006), mentioned again by Finger et al. (2013). The Navidad Formation directly overlies the Paleozoic basement, as do the overlying Licancheu, Rapel, and La Cueva Formations further to the east, beyond the town of Navidad. The contact between the Navidad and Licancheu Formations is described as (para?)concordant by Encinas (2006, p. 59), who nevertheless proposes a regression following Navidad deposition, succeeded by renewed transgression. It is implicit in this assumption that all of the Navidad Formation that must have been deposited many tens of kilometers farther to the east during the 1,500 $\mathrm{m}$ relative sea-level highstand, would have been eroded to expose the basement in this area before deposition of the Licancheu Formation. In the light of their interpretation of the Navidad Formation as representing deep water deposits, this is a necessary deduction, but it also requires dramatic sea-level changes on a similar scale. A much simpler and more logical alternative would be to consider the whole sequence as a typical onlap situation, therefore 
indicating large-scale marine transgression that continued the deepening trend proposed by us for the Navidad Formation. The shallow water aspect of the Licancheu and younger formations could therefore be due to their deposition in the proximity of the eastward-receding coastline, or partly to sea-level stillstands with progradation similar to those that produced the sandstone packages in the Navidad Formation, without necessarily exposing the underlying deposits to erosion. This would explain the (para?) concordant contacts observed in the field between all these different formations (Encinas, 2006).

If this interpretation of a major transgression interrupted by sea-level stillstands is correct, and considering the lithological similarity between all four formations, it would not be inappropriate to bundle the whole succession into the same unit. We propose the name 'Darwin Group', as Charles Darwin (1846) was the first scientist to describe this fascinating succession at Navidad.

\section{Conclusions}

Finger et al. (2013) now conclude that all of their samples are Burdigalian (20.4-16 Ma). We find this strange, considering that the obtained $\mathrm{Sr}$ ages of the Navidad Formation range from as old as $31.5 \mathrm{Ma}$ (Encinas, 2006), whereas pumice clasts are as young as $12.87 \mathrm{Ma}$. In the Lo Abarca sector, which may have a questionable correlation with the Navidad Formation (Gutiérrez et al., 2013), Sr ages of as low as 11.5 Ma have been recorded (Encinas, 2006).

Not being foraminifer experts, we have to rely on those who can claim to be. However, we would be rather interested to know whether all five index species had been wrongly identified, and if not, why such species can occur below their FAD and others not.

We disagree with the environmental interpretation provided by Finger et al. (2013), for reasons explained above, and maintain our view of a continental shelf to uppermost continental slope environment.

Considering the evidence, we do not question the in situ occurrence of molluscs and thus consider the sandstone packages to represent delta and shallow water (inner continental shelf) deposits, whereas the siltstone-shale packages are possibly outer continental shelf to uppermost continental slope deposits. The seismic section (Fig. 3) in fact suggests that they may be progradational delta slope deposits formed during sea-level stillstands. To accept that sea-level/ tectonic oscillations of $1,500 \mathrm{~m}$ or more occurred would stretch our imagination to the unbearable, especially in the absence of conditions favoring subduction erosion or large-scale crustal extension.

\section{References}

Achurra, L.E. 2004. Cambios del nivel del mary evolución tectónica de la Cuenca Neógena de Caldera, III Región. Masters Thesis (Unpublished), Universidad de Chile: 138 p.

Barreda, V.; Encinas, A.; Hinojosa, L.F. 2011 Polen y esporas de la Formación Navidad, Neógeno de Chile. Revista Chilena de Historia Natural 84: 341-355.

Bolli, H.M.; Saunders, J.B. 1985. Oligocene to Holocene low latitude planktic foraminifera. In Plankton Stratigraphy (Bolli, H.M.; Saunders, J.B.; PerchNielsen, K.; editors). Cambridge University Press, Cambridge Earth Science Series: 155-262.

Contardo, X.; Cembrano, J.; Jensen, A.; Díaz-Naveas, J. 2008. Tectono-sedimentary evolution of marine slope basins in the Chilean forearc $\left(33^{\circ} 30^{\prime}-36^{\circ} 50^{\prime} \mathrm{S}\right)$ : Insights into their link with the subduction process. Tectonophysics 459 (1-4): 206-218.

Contardo, X.; Mena, F. 2012. Evidencias, caracterización e implicancias del primer seep fósil descubierto en la costa emergida de Chile central. In Congreso Geológico Chileno, No. 13, Actas: 663-665. Antofagasta.

Darwin, C. 1846. Geological observations on South America. Being the third part the geology of the voyage of the Beagle, under command of Capt. Fitzroy, R.N. during the years 1832 to 1836 . Smith, Elder and Co.: 279 p. London.

Duff, D. 1978. Holmes' Principles of Physical Geology. Chapman \& Hall: 777 p. London.

Encinas, A. 2006. Estratigrafía y sedimentología de los depósitos marinos mio-pleistocénicos del área de Navidad (33ㅇำ $\left.00^{\prime}-34^{\circ} 30^{\prime} S\right)$, Chile central: Implicaciones con respecto a la tectónica del antearco. Ph.D. Thesis (Unpublished), Universidad de Chile: 177 p.

Encinas, A.; Finger, K.; Nielsen, S.; Lavenu, A.; Buatois, L.; Peterson, D.; Le Roux, J.P. 2008. Rapid and major coastal subsidence during the late Miocene in south-central Chile. Journal of South American Earth Sciences 25: 157-175.

Fine, I.V.; Rabinovich, A.B.; Bornhold, B.D.; Thomson, R.E.; Kulikov, E.A. 2005. The Grand Banks landslidegenerated tsunami of November 18, 1929: preliminary analysis and numerical modeling. Marine Geology 215: 45-57. 
Finger, K.L.; Encinas, A.; Nielsen, S.N. 2013. Comment on 'Evidence for an Early-Middle Miocene age of the Navidad Formation (central Chile): Paleontological, paleoclimatic and tectonic implications' of Gutiérrez et al. (2013, Andean Geology 40 (1): 66-78). Andean Geology 40 (3): 571-579.

Finger, K.L.; Nielsen, S.N.; DeVries, T.J.; Encinas, A.; Peterson, D.E. 2007. Paleontologic evidence for sedimentary displacement in Neogene forearc basins of central Chile. Palaios 22: 3-16.

Gutiérrez, N.M. 2011. Diversidad y cambios florísticos durante el Mioceno en Chile central. Masters Thesis (Unpublished), Universidad de Chile: 70 p.

Gutiérrez, N.M.; Hinojosa, L.F.; Le Roux, J.P.; Pedroza, V. 2013. Evidence for an Early-Middle Miocene age of the Navidad Formation (central Chile): paleontological, paleoclimatic and tectonic implications. Andean Geology 49: 66-78.

Hinojosa L.F. 2005. Cambios climáticos y vegetacionales inferidos a partir de paleofloras cenozoicas del sur de Sudamérica. Revista Geológica de Chile 32 (1): 95-115.

Hinojosa L.F.; Villagrán, C. 2005. Did the SouthAmerican Mixed Paleofloras evolve under thermal equability or in the absence of the Andes during the Tertiary? Palaeogeography, Palaeoclimatology, Palaeoecology 217: 1-23.

Hinojosa, L.F.; Armesto, J.J.; Villagrán, C. 2006. Are Chilean coastal rain forests pre-Pleistocene relicts? Evidence from foliar physiognomy, paleoclimate, and paleobiogeography. Journal of Biogeography 33: 331-341.

Jenkins, D.G. 1985. Southern mid-latitude Paleocene to Holocene planktic foraminifera. In Plankton Stratigraphy (Bolli, H.M.; Saunders, J.B.; PerchNielsen, K.; editors). Cambridge University Press: 263-282. Cambridge.

Kennett, J.P.; Srinivasan, M.S. 1983. Neogene Planktonic Foraminifera: A Phylogenic Atlas. Stroudsburg, Pennsylvania: Hutchinson Ross: 265 p.

Lipps, J.H. 1993. Fossil Prokaryotes and Protists. Blackwell Scientific Publications, Cambridge: 342 p.
Nielsen, S.N.; Glodny, J. 2006. The middle Miocene climate optimum in central and southern Chile: ${ }^{87} \mathrm{Sr} /{ }^{86} \mathrm{Sr}$ isotope stratigraphy on warm-water molluscs. In Congreso Geológico Chileno, No. 11, Actas 2: 93-96. Antofagasta.

Nielsen, S.N.; Frassinetti, D.; Bandel, K. 2004. Miocene Vetigastropoda and Neritimorpha (Mollusca, Gastropoda) of central Chile. Journal of South American Earth Sciences 17: 73-88.

Le Roux, J.P. 2009. Characteristics of developing waves as a function of atmospheric conditions, water properties, fetch and duration. Coastal Engineering 56: 479-483.

Le Roux, J.P.; Gómez, C.; Fenner, J.; Middleton, H. 2004. Sedimentological processes in a scarp-controlled rocky shoreline to upper continental slope environment, as revealed by unusual sedimentary features in the Neogene Coquimbo Formation, north-central Chile. Sedimentary Geology 165: 67-92.

Le Roux, J.P.; Nielsen, S.N.; Kemnitz, H.; Henríquez, A. 2008. APliocene mega-tsunami deposit and associated features in the Ranquil Formation, southern Chile. Sedimentary Geology 203: 164-180.

Le Roux, J.P.; Vargas, G. 2005. Hydraulic behavior of tsunami backflows: Insights from their modern and ancient deposits. Environmental Geology 49: 65-75.

Le Roux, J.P.; Jones, B.G. 1994. Lithostratigraphy and depositional environment of the Nowra Sandstone in the southwestern Sydney Basin, Australia. Australian Journal of Earth Science 41: 191-203.

Meón, H.; Torres, T.; Martínez-Pardo, R. 1994. Sporopollinic analysis in the Navidad Formation near Navidad (Chile). In Congreso Geológico Chileno, No. 7. Concepción, Actas: 488-490.

Rodríguez, M.P.; Pinto, L.; Encinas,A. 2012. Neogene erosion and relief evolution in Central Chile forearc $\left(33-34^{\circ} \mathrm{S}\right)$ as determined by detrital heavy mineral analysis. In Mineralogical and GeochemicalApproaches to Provenance (Troy Rasbury, E.; Hemming, S.R.; Riggs, N.R.; editors). Geological Society of America Special Papers 487: 141-162.

Welch, J.J. 2010. The 'Island Rule' and deep-sea gastropods: re-examining the evidence'. PLOS ONE 5 (1): e8776. doi: 10.1371/journal.pone.0008776.

$\overline{\text { Manuscript received: August 1, } 2013 .}$ 